\title{
Entrepreneur Training Needs Analysis: Implications On The Entrepreneurial Skills Needed For Successful Entrepreneurs
}

\author{
Rosnani Jusoh, University Putra Malaysia, Malaysia \\ Babak Ziyae, University Putra Malaysia, Malaysia \\ Soaib Asimiran, University Putra Malaysia, Malaysia \\ Suhaida Abd. Kadir, University Putra Malaysia, Malaysia
}

\begin{abstract}
This paper is one of the outcomes of the study from interview of 30 entrepreneurs in Malaysia, investigating the business competencies needed for successful in their business. In the paper, the training needs of entrepreneurs are identified and analysed with respect to a number of issues affecting business such as creativity and innovation, sources of business finance, accounting skills, financial management, areas in which the entrepreneurs find it difficult to acquire knowledge. The study confirm the view of entrepreneurship education makes a significant different in the performance of entrepreneurs, with entrepreneurs expressing a need for further training and education in specific business issues.
\end{abstract}

Keywords: Entrepreneurship Education; Training Needs Analysis; Business Competencies

\section{INTRODUCTION}

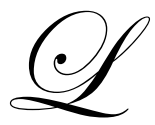

ife in a knowledge-based economy global in the world without boundaries, an entrepreneur needs to equip themselves with new skills and restructure priorities in applying high technology and entrepreneurial culture that is dynamic. This is in line with the national vision that outlines the development of human resources through increased knowledge of the draft "K-Economy Master Plan" to guide the generation of knowledge workers to increase the national output. Gross Domestic Product (GDP) growth will be driven by knowledge-based industries in all sectors, especially manufacturing and services sectors. (OECD, 1997) describes a knowledge-based economy to produce designs that can compete and strengthen the process of growth and plays an important role in promoting innovation to the firm. Therefore, entrepreneurs need to enhance knowledge skills and competencies as the k-economy is the agenda for the development of the country today. Timmons (2004) points out by stressing entrepreneurship stressing entrepreneurship as strongly allied with economic expansion at global level and countries with high levels of entrepreneurial motion have their economic performance at above average growth rate.

The implementation of ASEAN Free Trade Area (AFTA) in 2003, of course, particularly impact on Small and Medium Enterprises. However, this should not be regarded as a challenge for entrepreneurs to improve the quality of products and services through improvements in knowledge and skills. AFTA agreement was signed by Malaysia, together with the other 9 ASEAN countries in order to establish the business world without boundaries. Upon execution, it will cover approximately 450 million consumers across ASEAN. This is an opportunity that should be snapped up by entrepreneurs, especially small and medium employers. In line with the concept of k-economy and the coming of AFTA, the entrepreneurs need to equip themselves with knowledge to face the challenges ahead and is a critical factor that enhances competitive advantage.

Entrepreneurs who are knowledgeable are trained to compete in the era of globalization of business in line with changes in technology and also be able to use information communication and technology (ICT) applications in daily operations. A radical technological change requires a dynamic entrepreneur. This is because the skills needed 
to be changed and improved over time. Continuous training should be implemented as a culture in the life of an entrepreneur. This means that lifelong learning should be applied as a culture and do not stop after graduation or business venture successful. Entrepreneurs need to be equipped with various skills. As a result, enterprise education will be complementary to the opportunity for entrepreneurs to enhance their knowledge and skills in developing and preparing themselves for the challenges and global competition (Jenning, 1994).

Ibrahim Abu Shah (2005) describes the policy environment under the New Economic Policy (NEP) and National Development Policy (NDP) is far different from the current environment and future scenarios. This scenarios and realities challenge the new policy options and its implementation. Among the future challenges that must be signed are:

1. Intensification of international competition from the effects of globalization and liberation.

2. Transformation economic structure claims of natural resource based economy to a knowledge-based economy or k-economy.

3. Facilities potential 'digital divide' between regions, urban strata - rural areas and among ethnic groups.

4. $\quad$ Claims of increase 'Total Factor Productivity "(TFP)

5. Scenario of world economic growth is lower in the coming decades.

While the study by the CRIC (2000) entitled "Defining the Role of Knowledge-Intensive Business Services in the Economy", shows a knowledgeable entrepreneur is able to improve their business performance and compete in global market. The study also explains that a knowledgeable entrepreneur also enables them to invest in their various fields of flexible and intangible. This investment will affect competition in the workforce with high intellectual that becomes an intangible asset such as ability to perform the job, having intellectual property and good communication technology system and be able to attract customers. The question is to what extent the existing level of skills and knowledge of entrepreneurs and what training requirements needed by entrepreneurs to face the global market?

\section{LITERATURE REVIEW}

Previous research showed that the formation of potential entrepreneurs through education and entrepreneurial training can help economic growth. The entrepreneurs' support system through entrepreneurship education design can stimulate and facilitate entrepreneurial activities that can reduce the amount of unemployment, increase the formation of new businesses and reduce the number of business fail (Hatten \& Ruhland, 1995; Ronstadt, 1985; and Hensemark, 1998). Entrepreneurship education is the process of providing individuals with the ability to recognize commercial opportunities and insight, self esteem, knowledge and skills to act on them. It includes instruction in opportunity recognition, commercializing a concept, marshalling resources in the face of risk and initiating a business venture. It also includes instruction in business disciplines such as management, marketing, information systems and finance (Jones and English, 2004).

Education and entrepreneurial training is also one of the economic strategy that is globally competitive and to increase employment opportunities through innovative entrepreneurs to create new products, resulting from changes in market demand by consumers. As a result of this change in the business -entrepreneurs needed to meet the needs of the community. As a study carried out shows at least the growth of the economy is related to innovation and the creation of new products (Porter, Ketel Delago, 2007). Dana (1993) describes through entrepreneurial training and education provided to the entrepreneurs will be able to contribute their knowledge, skills and experience.

While the study by Upton, Sexton, \& Moore (1995) found that there is a relationship between entrepreneurship education and training on the tendency to start a business and the success of a business. Apart from the attitude of entrepreneurs who constantly upgrade their skills and knowledge in entrepreneurship education, entrepreneurs must have the ability to take risks in carrying out their entrepreneurial activities. This is because previous research has shown that successful entrepreneurs have the characteristic of willingness to take risks in business (McCelland, 1981). This is for entrepreneurs to conduct their business activities in the environment at risk and they cannot refrain from taking risks to achieve success. This was what the key to or characteristics of 
successful entrepreneurs (Mintzberg and Waters, 1982). Accordingly McConnell (2003) explained that the training will be more effective if the training needs analysis carried out comprehensively in advance.

Study by Wertenbroch and Pietri (2005) on training needs analysis for the entrepreneur seeks to identify the profile, training and development needs, training methods and skills and competencies needed by entrepreneurs, especially in the face of challenges such as globalization, changing work environment, dealing with risk and the importance of building teamwork. In this study, researchers will conduct training needs analysis of entrepreneurship education to determine the level of skills and identify training needs in entrepreneurship education among entrepreneurs.

\section{METHODOLOGY}

This is a review of training needs analysis of education entrepreneurs. The study involved interview. Technique is a qualitative study of methods of collecting data through interviews is the most common in studies involving a limited number of samples (Bogdan \& Biklen, 1992).

Interview that had been used in this study was to obtain information relating to the paradigm and interpret the training needs of entrepreneurial education. Interpretation of data is a process to clarify and define the situation to a situation of others. According Scahron (1995), interactionism practitioners often stress that the human is using perspective to define reality. Interview technique is the best and is often used by many researchers to get the latest information from an individual (Brenner, 1985; Minichiello et al. 1990 and Taylor \& Bogdan, 1984). Using interactionism tradition, interviewing techniques is used to obtain better data to reach the field experience (Silverman, 1993). Hence the argument about the strength of interviewing techniques for both chat and interviews the people interviewed are able to explore the meaning of the questions raised, and can produce spontaneous response. It is able to obtain detailed information as a result of good relations between the two, as well as a reliability that can be defended in scientific research.

Through interviews, data collected will be categorized and processed to obtain information on the matter under review. In addition, this method will allow researchers to collect opinions, thoughts, views and experiences in the form of a direct statement of their own study. Therefore, according to Lindlof \& Taylor (2002) structured interviews are the best way when we want to collect information and information about the attitudes or beliefs. However, researchers also need to undertake in-depth interview by "depth interview." Therefore, this study has to be done by conducting structured interviews and it must be in depth. During the process of data gathering, research prior to contacting the selected respondent and make an appointment for first visit. During the first visit other than a background of respondents, the researchers have to provide the structure of questions that need answers from the respondents. Given the structure of some questions that require time for respondents to answer, the researchers made an appointment for an in-depth interviews with entrepreneurs based on a written reply by the respondents to obtain clear information and more detailed.

All the data collected from respondents were analyzed using mean, standard deviation. Mean score was interpreted into two parts as follows:

Table 1

\begin{tabular}{|l|c|c|}
\hline Mean Score & $\begin{array}{c}\text { Existing Level of Entrepreneurial } \\
\text { Skills Entrepreneur }\end{array}$ & $\begin{array}{c}\text { Level of Entrepreneurial } \\
\text { Skills Training Needs }\end{array}$ \\
\hline $1.00-2.60$ & Unskilled & Not Essential \\
\hline $2.61-4: 21$ & Medium Skilled & Necessary \\
\hline $4: 22$ to $5: 00$ & Skilled & Very Essential \\
\hline
\end{tabular}




\section{FINDINGS}

The table below shows the existing level of entrepreneurial skills and entrepreneurial skills training needs of entrepreneurs in the study. Statistic analysis shows that entrepreneurs are reviewed as a whole is at a moderate level of skill with mean $=3.51$. The highest level of entrepreneurial skills is the skill to sell, and leadership skills with a mean $=3.93$. Followed by the skills of market analysis, human resource management, supplier management and business law respectively mean $=3.83$. The entrepreneurial skills of the lowest owned by the respondents is the expertise in e-commerce or Internet use $($ mean $=2.77)$, followed by applying the skills of other software $($ mean $=$ $2.83)$ and the skills of legal workers $($ mean $=2.97)$.

Related to the training needs of the entrepreneurial skills of the respondents indicated they generally require entrepreneurial skills training (mean $=4.11$ ). Statistical analysis showed that they need training in all entrepreneurial skills, who asked with a mean of 3.27 to $4.73 \mathrm{~min}$. Whilst entrepreneurial skills training which is required by the respondent is to plan marketing and advertising skills to promote their own or mean $=4.73$, followed by the skills to run the business (mean $=4.63$ ), skills to be more creative and innovative (mean $=4.60)$, accounting management skills and selling skills (mean $=4.60)$ and the skill set the price of the product or services correctly $($ mean $=4.50)$.

Table 2

Skill Level Schedule of Entrepreneurship and Entrepreneurial Skills Training Requirements Respondents

\begin{tabular}{|c|c|c|}
\hline Entrepreneurial Skills & Min Skill owned & Min Training Needs \\
\hline Identify business opportunities & $3: 03$ & 3.90 \\
\hline E - Commerce / Internet & 2.77 & 4:07 \\
\hline Excel & $3: 37$ & 4:03 \\
\hline Word & 3.63 & $4: 20$ \\
\hline Other Software Applications & 2.83 & $4: 20$ \\
\hline Administration Plan & $3: 20$ & 4.63 \\
\hline Marketing Plan & $3: 27$ & 4.73 \\
\hline Production Plan & $3: 47$ & $4: 40$ \\
\hline Business Plan & $3: 40$ & $4: 13$ \\
\hline Promotions and Advertising & 3.70 & 4.73 \\
\hline Market analysis / segmentation & 3.87 & $3: 27$ \\
\hline Human Resource Management & 3.87 & $4: 17$ \\
\hline Law - Employment Law & 2.97 & $4: 17$ \\
\hline Creativity / Innovation & $3: 43$ & 4.60 \\
\hline Supplier Management & 3.83 & $4: 13$ \\
\hline Business Law & 3.83 & 3.83 \\
\hline Language Skills & 3.63 & 3.97 \\
\hline Accounting and Financial Management & 3.63 & 4.60 \\
\hline Employee Management & $3: 30$ & $3: 40$ \\
\hline Fees and Interest & $3: 37$ & $3: 53$ \\
\hline Identify the premises for business & $3: 57$ & $4: 13$ \\
\hline Leadership Skills & 3.93 & 3:07 \\
\hline Time Management & 3.67 & 3.83 \\
\hline Business Financial Resources & $3: 57$ & 4:07 \\
\hline Pricing of products / services appropriately & 3.70 & $4: 50$ \\
\hline Operations Management & 3.60 & $4: 17$ \\
\hline Providing Services to Customers & 3.63 & $4: 45$ \\
\hline Selling Skills & 3.93 & 4.60 \\
\hline Average Min & $3: 51$ & $4: 11$ \\
\hline
\end{tabular}




\section{CONCLUSION}

The study showed that the level of entrepreneurial skills of the entrepreneurs surveyed are moderately skilled, and they feel they need entrepreneurial skills training in areas such as to enhance creativity and innovation, the skills to make a business account, creating promotions and advertising skills, skills set the right price and selling skills. This study shows that entrepreneurs react to changes in the current business environment that requires creative and innovative entrepreneurs to provide goods and services more competitive and viable (Rosnani and Soaib Asimiran, 2007). Apart from that, through training and entrepreneurial education to be given to entrepreneurs based on the skills needed by entrepreneurs in this study can contribute their knowledge, skills and experience to the business of the Dana (2001).

From this study indicate that entrepreneurs still need knowledge related to the business in order to make their businesses more robust and competitive. They believe the increase in knowledge; skills will be able to expand to larger and more successful. As a result, they need to provide appropriate entrepreneurial training to the training needs of entrepreneurs who desire to reduce the wastage of time and training costs.

\section{AUTHOR INFORMATION}

Rosnani Jusoh, Lecturer at Science and Technical Education Department, Faculty of Educational Studies, University Putra Malaysia; Research fields: Entrepreneurship and Commerce Education and Teacher Education.

Babak Ziyae, PhD Candidate of Management (Entrepreneurship), Graduate School of Management, University Putra Malaysia; Research fields: Entrepreneurship.

Dr. Soaib Asimiran, Lecturer at Science and Technical Education Department, Faculty of Educational Studies, University Putra Malaysia; Research fields: University Governance, Higher Education Management / Leadership, Quality Management in Higher Education, Entrepreneurship and Entrepreneurship Education.

Dr. Suhaida Abd. Kadir, Lecturer at Science and Technical Education Department, Faculty of Educational Studies, University Putra Malaysia; Research fields accounting education, Entrepreneurship and Entrepreneurship Education.

\section{REFERENCES}

1. AFTA, http://www.wordiq.com/definition/ASEAN_Free_Trade_Area

2. Bogdan, R., \& Biklen, R.C. (1992). Qualitative research for education: An introduction to theory and methods. Boston: Allyn-Bacon.

3. CRIC (2000). Defining the role of knowledge-intensive business services in the economy. http://www.cric.ac.uk/cric/compprojects/project-6.htm

4. $\quad$ Dana, L. P. (1993). Towards internalization of entrepreneurship: two models in Eastern Africa. Journal of International Business and Entrepreneurship. 2(2): 74

5. Gay, L.R. (1996). Educational research: Competencies for analysis and application $5^{\text {th }}$ edition, Prentice Hall, Upper Saddle River, NJ.

6. Hansemark, O. (1998). The effects of an entrepreneurship programme on need for achievement and locus of control of reinforcement. International Journal of Entrepreneurship Behaviour and Research, $4(1), 28$

7. Hatten, T. \& Ruhland (1995). Student attitudes toward entrepreneurship as affected by participation in an SBI program. Journal of Education for Business, 7(4), 224-227.18

8. Ibrahim Abu Shah (2005). Pembangunan Sumber Manusia Melayu Dalam Arus Globalisasi. Paper Presented at Musyawarah Perdana Ekonomi 14-15 Julai 2005, Hotel Residence, K.L.

9. Jones, C., \& English J. (2004). A contemporary approach to entrepreneurship education. Emerald Education and Training. 46(8) 416-423.

10. Jennings, D.F. (1994). Multiple perspective of entrepreneurship. Ohio: South Western Publishing. 
11. Kuratko, D. F. (2006). Entrepreneurship: theory, process, practice (7th ed.). Mason, OH: Thomson South-Western.

12. Lindlof. T.R. \& Taylor, B. C. (2002). Qualitative Communication Research Methods. Second Edition. Sage.

13. Mintzberg, H. \& Waters, J. A., (1982). Tracking strategy in an entrepreneurial firm. Academy of Management Journal, 25, 465-499.

14. McClelland, D.C. (1981). The achieving society. Princeton, NJ: Van Nostrand.

15. McConnel, J. H. (2003). How to identify your organization's training needs. New York: Amazon Books.

16. OECD. (1997). Information Technology and the future of post-secondary education. Paris: OECD.

17. Porter, M. E., Ketels, C., \& Delgado, M. (2007). The microeconomic foundations of prosperity: findings from the business competitiveness index. The Global Competitiveness Report 2007-2008. http://www.forumdaliberdade.com.br/fl2009/apresentacao_arquivos/Chapter2.pdf

18. Rosnani Jusoh dan Soaib Asimiran (2007). Cabaran usahawan di era globalisasi. Paper Work at Seminar Kebangsaan Pendidikan Teknikal dan Vokasional 2007. Hotel Eastin, Petaling Jaya.

19. Silverman, D. (1993). Interpreting qualitative data: methods for analysing talk, text, and interaction. Thousand Oaks, CA: Sage.

20. Taylor, S., \& Bogdan, R. (1984). Introduction to qualitative research methods: The search for meanings $2^{\text {nd }}$ edition, New York: John Wiley \& Sons.

21. Timmons, J. (2004), New Venture Creation: Entrepreneurship in the $21{ }^{\text {st }}$ century, Homewood, IL: Richard D. Irwin Publishing

22. Upton, N. Sexton, D. \& Moore, C. (1995). Have we made difference? An examination of career activity of entrepreneurship major since 1984. Frontiers of Entrepreneurship Research. 25

23. Wertenbroch, A., \& Pietri, J. (2005). Training needs analysis. Technological Toolkit for Entrepreneurs. INSEAD. http://www.tte40.net/images/tte40 